\title{
CHEMICAL CONSTITUENTS AND BIOLOGICAL ACTIVITY OF THREE TANZANIAN WILD MUSHROOM SPECIES
}

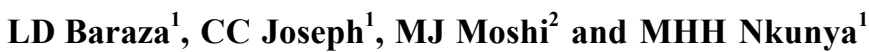 \\ ${ }^{1}$ Department of Chemistry, University of Dar es Salaam, P.O. Box 35061, Dar es Salaam, \\ Tanzania; \\ ${ }^{2}$ Institute of Traditional Medicine, Muhimbili University College of Health Sciences, P.O. Box \\ 65005, Dar es Salaam, Tanzania \\ Email:Cosam@chem.udsm.ac.tz
}

\begin{abstract}
The three Tanzanian wild mushroom species Termitomyces letestui, Lactarius edulis and Agaricus sp. aff. arvensis yielded ergosterol, 5,8-peroxyergosterol and ergosta-5,22-dien-3 $\beta$-ol, and a mixture of ergosterol, ergosta-7,22-dien-3 $\beta$-ol and ergosta-7-en-3 $\beta$-ol whose composition was deduced from gas chromatography/mass spectroscopic (GC/MS) analysis of the trimethysilylated mixture. GC/MS analysis of the lipid fraction from $\mathrm{T}$. letestu revealed the presence of linoleic $\left(C_{18: 2}\right)$, stearic $\left(C_{18: 0}\right)$, oleic $\left(C_{18: 1}\right)$, palmitic $\left(C_{16: 0}\right)$, pentadecanoic $\left(C_{15: 0}\right)$ and myristic $\left(C_{14: 0}\right)$ acid. Polar T. letestui and L. edulis fractions yielded $\alpha, \alpha 1,1^{\prime}$-trehalose and mannitol. Some of the crude extracts from the three mushroom species showed mild antimicrobial, mosquito larvicidal and cytotoxic activities. The chemical composition and antimicrobial activities infer that the three mushroom species are potential functional food substrates.
\end{abstract}

\section{INTRODUCTION}

Termitomyces is a tropical edible mushroom genus that occurs in symbiosis with termites (Harkonen et al. 2003). T. letestui is one of the Termitomyces species growing in Tanzania and usually appears at the onset of rains. Among the few reported chemical analyses of Termitomyces species include the recent isolation of neuritogenic cerebrosides from the edible Chinese mushroom Jizong [T. albuminosus (Berk.) Heim.] (Qi et al. 2000). So far, there are no reports on either chemical constituents or biological activity of $T$. letestui and this prompted us to include this mushroom species in our ongoing chemical analysis of Tanzanian wild mushrooms for bioactive and nutritional constituents (Mdachi et al. 2004).

Other Tanzanian wild mushrooms Lactarius eduli (Russulaceae), and Agaricus sp. aff. arvensis (Agaricale; Harkonen et al., 2003), that grow around decayed wood and termite hills in coastal areas of Tanzania, were also selected for our investigations, owing to their mild activity in the brine shrimp test (Meyer et al. 1982). Agaricus compounds include amino acids, steroids and physiologically active phenylhydrazones of glutamic acid (Chulia et al. 1988, Kawakishi et al. 1998).

In Africa, the mostly edible Lactarius species grow wildly in miombo woodlands, their colour and taste being associated with fatty acid esters metabolized as a response to injury (Bernardi et al. 1992, Sterner and Anke 1995, Stadler and Sterner, 1998). In a recent study, 15 out of 27 Tanzanian Lactarius species were for the first time scientifically described (Karhula et al. 1998), indicating the great abundance of Lactarius species in Tanzania. 


\section{MATERIALS AND METHODS General experimental procedures} Column chromatography: Silica gel 60 (0.063 - $0.200 \mathrm{~mm}$, Merck), gradient elution (petrol ether/EtOAc); TLC: Silica gel $60 \mathrm{~F}_{254}$ (Merck) pre-coated on $\mathrm{Al}$ or plastic plates; visualization: UV-VIS and anisaldehyde (Stahl, 1969); recrystallization: Petrol ether/EtOAc (9:1 v/v) or $\mathrm{MeOH}$; IR: Bruker IFS 28; specific rotation: Perkin Elmer Model 341 polarimeter; ${ }^{1} \mathrm{H}$ and ${ }^{13} \mathrm{C}$ NMR spectra: Varian Unity 300 or Bruker Avance DPX 300 at $300 \mathrm{MHz}$ for ${ }^{1} \mathrm{H}$ and 75 $\mathrm{MHz}$ for ${ }^{13} \mathrm{C} \mathrm{NMR}$, or Varian Inova 500 or Bruker Avance DRX 600 at 500 or 600 $\mathrm{MHz}$ for ${ }^{1} \mathrm{H} \mathrm{NMR}$, inverse techniques for HMQC and HMBC; chemical shifts in ppm [internal standard TMS $(\delta=0 \mathrm{ppm})$ for ${ }^{1} \mathrm{H}$ and $\mathrm{CDCl}_{3}(\delta=77.0 \mathrm{ppm})$ for $\left.{ }^{13} \mathrm{C} \mathrm{NMR}\right]$; high resolution negative ion ESI MS: Bruker Apex III FT Ion Cyclotron Resonance (FT-ICR) MS with an Infinity ${ }^{\mathrm{TM}}$ cell, a 7.0 $\mathrm{T}$ superconducting magnet, an RF-only hexapole ion guide and an external electrospray ion source; sample solutions introduced continuously via a syringe pump, flow rate of $120 \mu \mathrm{l} / \mathrm{h}$.

\section{Mushroom materials}

Fruiting bodies of L. edulis and T. letestui were collected from Mafinga district, Iringa region in Tanzania (February - April 2003 and 2004) and authenticated at the Department of Molecular Biology and Biotechnology, University of Dar es Salaam where voucher specimens are preserved. Agaricus sp. aff. arvensis was collected from the University of Dar es Salaam main campus (April - May 2003 and 2004). The fruiting bodies immediately after collection were first oven dried $\left(40{ }^{\circ} \mathrm{C}\right)$ for one day and then carefully dried at room temperature $\left(25{ }^{\mathrm{O}} \mathrm{C}\right)$ for one week.

\section{Extraction and isolation}

Dried, ground fruiting bodies of $T$. letestui (403 g), L. edulis (200 g) and Agaricus sp. aff. arvensis (203 g) were soaked in petrol ether, dichloromethane and $\mathrm{EtOH}$ or $\mathrm{MeOH}$. A $\mathrm{MeOH}$ solution of the T. letestui $\mathrm{EtOH}$ extract ( $32 \mathrm{~g})$ on cooling in the fridge at $4{ }^{\circ} \mathrm{C}$ formed white crystals of mannitol and column chromatography of the concentrated filtrate yielded ergosterol, a mixture of free fatty acids (GC-MS), mannitol and $\alpha, \alpha 1,1^{\prime}$-trehalose (2). Vacuum liquid chromatography (VLC) of the Lactarius edulis $\mathrm{MeOH}$ extract $(10 \mathrm{~g})$ followed by recrystallization yielded ergosta-5,22-dien$3 \beta$-ol, while the more polar VLC factions on crystallization in $\mathrm{MeOH}$ gave mannitol. The $2^{\text {nd }}$ VLC fraction of the Agaricus sp. aff. arvensis $\mathrm{EtOH}$ extract $(4.38 \mathrm{~g})$ consisted of a mixture of ergosterol, ergosta-7,22dien-3 $\beta$-ol and ergosta-7-en-3 $\beta$-ol and upon filtration the supernatant solution on column chromatography and then recrystallization gave pure ergosterol. Recrystallization of VLC fraction 3 (petrol ether/EtOAc, 9:1 v/v) yielded white crystals of compound 1 . The rest of the polar fractions contained mixtures of fluorescing compounds that could not be separated even by reversed phase HPLC.

\section{GC-MS analysis}

The fatty acid composition of the lipid fraction from $T$. letestui as well as that of the trimethylsilylation mixture of sterols from Agaricus sp. aff. arvensis extracts product was determined by coupled, temperature programmed GC-MS analysis using an MD 800 GC-MS System (Fisons Instrument). The MS of each individual compound was compared with those contained in a computerized database.

\section{Biological assays}

Brine shrimp test, antimicrobial and mosquito larvicidal assays were carried out as described in the literature (Meyer et al. 1982, Moshi et al. 2004 and Joseph et al. 2004).

\section{RESULTS}

The L. edulis petrol ether, dichloromethane and $\mathrm{MeOH}$ extracts, and T. letestui $\mathrm{EtOH}$ extract exhibited mild cytotoxic activity (brine shrimp test $-\mathrm{BST}, \mathrm{LC}_{50}=88,69.6$, 26.7 and $69.7 \mu \mathrm{g} / \mathrm{ml}$ respectively). The 
Agaricus sp. aff. arvensis EtOH extract had the highest cytotoxic activity $\left(\mathrm{LC}_{50}=19.9\right.$ $\mu \mathrm{g} / \mathrm{ml}$ ) and as such it was also evaluated for lethality against An. gambiae mosquito larvae, whereby it exhibited mild activity $\left(\mathrm{LC}_{50}=0.52,0.18\right.$ and $0.15 \mathrm{mg} / \mathrm{ml}$ after 24, 48 and $72 \mathrm{~h}$ exposure).

The crude dichloromethane and EtOH extracts from T. letestui and Agaricus sp. aff. arvensis exhibited moderate activity against the bacteria Vibrio cholerae and Escherichia coli, and the fungus Candida albicans (Table 1), while Agaricus sp. aff. arvensis $\mathrm{EtOH}$ extract exhibited high activity against the bacterium Basillus anthracis, and mild activity against Salmonella typhimurium, Staphylococcus aureus, Klebsiella pneumoniae and Proteus sp. (Table 1). Ergosterol showed weak activity against Basillus anthracis and $V$. cholerae.

Table 1: Antimicrobial activity of some crude Agaricus sp aff arvensis and T. letestui extracts and egesterol

\begin{tabular}{l|ccccc}
\hline \multirow{2}{*}{ Organism } & \multicolumn{4}{|c}{ Zones of inhibition (mm) } \\
\cline { 2 - 6 } & $\begin{array}{c}\text { Agaricus } \\
\text { sp.(EtOH) }\end{array}$ & Ergosterol & $\begin{array}{c}\text { T. letestui } \\
\left(\mathrm{CH}_{2} \mathrm{Cl}_{2}\right)\end{array}$ & Ampicillin & Miconazole \\
\hline Escherichia coli & $6.5 \pm 0.16$ & 0 & $11 \pm 0.6$ & $26 \pm 0.2$ & - \\
Salmonella boydii & 0 & 0 & 0 & $18 \pm 0.1$ & - \\
Salmonella typhimurium & $11 \pm 0.5$ & 0 & 0 & $25 \pm 0.2$ & - \\
Klebsiella pneumoniae & $7 \pm 0.14$ & 0 & 0 & $20 \pm 0.5$ & - \\
Basillus anthracis & $24 \pm 0.2$ & $8.2 \pm 0.2$ & 0 & $27 \pm 0.2$ & - \\
Staphylococcus aureus & $10 \pm 0.1$ & 0 & 0 & $30 \pm 0.1$ & - \\
Vibrio cholerae & $10 \pm 0.1$ & $6.5 \pm 0.5$ & $10 \pm 0.3$ & $17 \pm 0.4$ & - \\
Proteus sp. & $8 \pm 0.3$ & 0 & 0 & $15 \pm 0.5$ & - \\
Candida albicans & $6.5 \pm 0.16$ & 0 & $12 \pm 0.5$ & - & $20 \pm 0.5$ \\
\hline
\end{tabular}

Repeated chromatography of the EtOH or $\mathrm{MeOH}$ extracts from T. letestui, L. edulis and Agaricus sp. aff. arvensis yielded ergosterol, $5 \alpha, 8 \alpha$-epidioxy-ergost- 6,22 dien-3 $\beta$-ol (5,8-peroxyergosterol, 1$)$, ergosta-5,22-dien-3 $\beta$-ol and an inseparable mixture of ergosterol, ergosta-7,22-dien-3 $\beta$ ol and ergosta-7-en-3 $\beta$-ol as established from GC-MS analysis of the trimethylsilylated mixture.

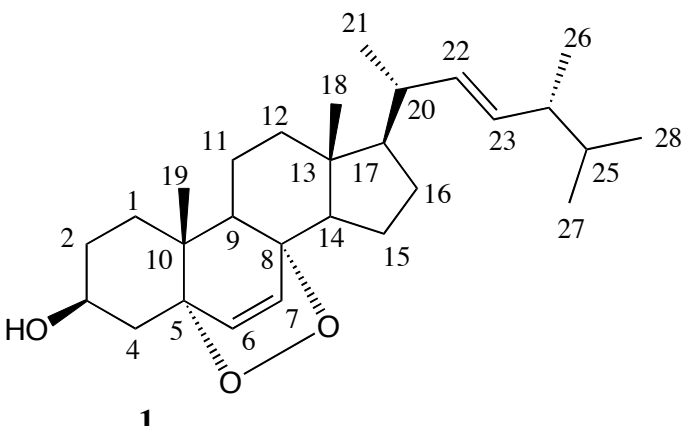

1

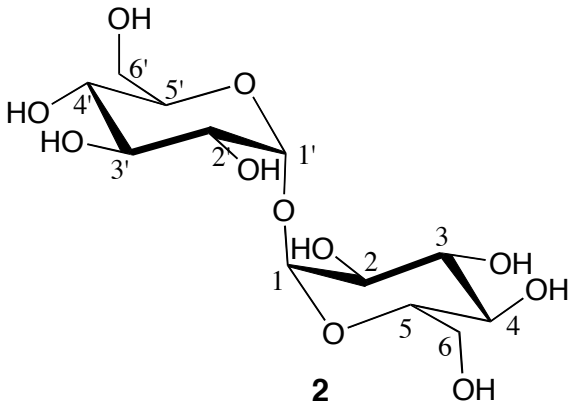

2 
$5 \alpha, 8 \alpha$-Epidioxy-ergost-6,22-dien-3 $\beta$-ol $(5,8$ peroxyergosterol) (1) exhibited the following properties: White crystals; m.p. $170-171^{\circ} \mathrm{C}$, m.p. $178-179{ }^{\circ} \mathrm{C}$ (Kocor and Szalowska 1972); yield, $7 \mathrm{mg} ; R_{f}=0.5$ (20\% EtOAc/hexane); anisaldehyde - blue; EI-MS, $m / z$ (\% rel. int.) $400\left(\left[\mathrm{M}-\mathrm{C}_{2} \mathrm{H}_{4}\right]^{+}\right.$, 35), 398 (40), 363 (25), 271 (100), 255 (80), 229 (30), 213 (30) and 147 (35); ESIFT-ICR-MS (positive ion mode), $\mathrm{m} / \mathrm{z}$ $451.31871\left([\mathrm{M}+\mathrm{Na}]^{+}\right)$, calc. for $\mathrm{C}_{28} \mathrm{H}_{44} \mathrm{O}_{3} \mathrm{Na}=451.31827 ;{ }^{1} \mathrm{H}$ NMR, $\delta 0.80$ $(3 \mathrm{H}, s, \mathrm{H}-18), 0.81(3 \mathrm{H}, s, \mathrm{H}-19), 0.90$ $(3 \mathrm{H}, d, J=7 \mathrm{~Hz}, \mathrm{H}-27), 0.92(3 \mathrm{H}, d, J=7$ $\mathrm{Hz}, \mathrm{H}-26), 0.99(3 \mathrm{H}, d, J=7 \mathrm{~Hz}, \mathrm{H}-28)$, $1.01(3 \mathrm{H}, d, J=7 \mathrm{~Hz}, \mathrm{H}-21), 1.22(1 \mathrm{H}, m$, $\mathrm{H}-17), 1.35$ and $1.75(2 \mathrm{H}$, both $m, \mathrm{H}-16)$, $1.44(1 \mathrm{H}, m, \mathrm{H}-25), 1.50(1 \mathrm{H}, m, \mathrm{H}-14)$, 1.5 and $1.82(2 \mathrm{H}$, each $m, \mathrm{H}-15), 1.56(1 \mathrm{H}$, $m, \mathrm{H}-9), 1.58(2 \mathrm{H}, m, \mathrm{H}-11), 1.82(2 \mathrm{H}, m$, $\mathrm{H}-1), 1.84(1 \mathrm{H}, m, \mathrm{H}-20), 1.90$ and 2.08 $(2 \mathrm{H}$, each $m, \mathrm{H}-4), 1.94(2 \mathrm{H}, m, \mathrm{H}-12)$, $2.06(1 \mathrm{H}, m, \mathrm{H}-24), 2.14(2 \mathrm{H}, m, \mathrm{H}-2)$, $3.97(1 \mathrm{H}, m, \mathrm{H}-3), 5.15(1 \mathrm{H}, d d, J=15.3$, $8 \mathrm{~Hz}, \mathrm{H}-23), 5.24(1 \mathrm{H}, d d, J=15.4,8.2 \mathrm{~Hz}$, $\mathrm{H}-22), 6.23(1 \mathrm{H}, d, J=8.6 \mathrm{~Hz}, \mathrm{H}-6)$ and $6.49(1 \mathrm{H}, d, J=8.4 \mathrm{~Hz}, \mathrm{H}-7)$; and ${ }^{13} \mathrm{C}$ NMR, $\delta 135.26$ (C-6), 135.06 (C-23), 132.16 (C-22), 130.62 (C-7), 82.12 (C-5), 79.39 (C-8), 66.47 (C-3), 56.5 (C-17), 51.69 (C-9), 51.08 (C-14), 44.59 (C-10), 42.90 (C-20), 42.81 (C-13), 39.80 (C-24), 39.38 (C-12), 36.97 (C-4), 34.74 (C-2), 33.12 (C-25), 30.67 (C-15), 30.19 (C-1), 28.73 (C-21), 28.73 (C-16), 20.97 (C-28), 20.71 (C-11), 19.73 (C-19), 18.27 (C-27), 17.65 (C-26) and 12,97 (C-18).

$\alpha$-D-Glucopyranosyl- $(1 \rightarrow 1)-\alpha-D$ -

glucopyranoside ( $\alpha, \alpha 1,1^{\prime}$-trehalose, 2$)$ had the following properties: White crystals; mp. $120-123{ }^{\circ} \mathrm{C}$ trehalose dihydrate m.p. $97-99{ }^{\circ} \mathrm{C}$ (Matsuura et al. 2002); yield, $0.5 \mathrm{~g} ;[\alpha]_{\mathrm{D}}^{29.1}=+197.29^{\mathrm{O}}(\mathrm{c}, 0.3, \mathrm{MeOH})$, $[\alpha]_{\mathrm{D}}^{23}=+189.5^{\mathrm{O}} \quad$ (c, $\left.0.20, \mathrm{MeOH}\right)$ (Matsuura et al., 2002); anisaldehyde - no reaction; IR, $v_{\max }(\mathrm{KBr}) 3501,2879-2991$, $1457,1398,1354,1332,1311,1240,1211$, 1149, 1128, 1098, 1084, 1061, 1030 and $1015 \mathrm{~cm}^{-1}$; EI-MS, $\mathrm{m} / z$ (\% rel. int.) 325
$\left([\mathrm{M}-\mathrm{OH}]^{+},<10\right), 235(10), 163(30), 145$ (20), 133 (15), 116 (7), 103 (100) and 74 (72): ESI-FT-ICR-MS (positive ion mode), $\mathrm{m} / \mathrm{z} 365.10566\left([\mathrm{M}+\mathrm{Na}]^{+}\right)$, calc. for $\mathrm{C}_{12} \mathrm{H}_{22} \mathrm{O}_{11} \mathrm{Na}=365.1054326 ;{ }^{1} \mathrm{H}$ NMR, $\delta$ $3.45(2 \mathrm{H}, d d, J=9.2,3.9 \mathrm{~Hz}, \mathrm{H}-4$ and $\mathrm{H}-$ $\left.4^{\prime}\right), 3.64(2 \mathrm{H}, d d, J=9.9,3.9 \mathrm{~Hz}, \mathrm{H}-2$ and $\left.\mathrm{H}-2^{\prime}\right), 3.76(2 \mathrm{H}, d d, J=11.9,5.2 \mathrm{~Hz}, \mathrm{H}-$ $6 \beta^{\prime}$ and $\left.\mathrm{H}-6 \beta\right), 3.84\left(2 \mathrm{H}, m, \mathrm{H}-5\right.$ and $\left.\mathrm{H}-5^{\prime}\right)$, $3.87\left(2 \mathrm{H}, m, \mathrm{H}-3\right.$ and $\left.\mathrm{H}-3^{\prime}\right), 3.88$ ( $m, \mathrm{H}-6 \alpha$ and $\left.\mathrm{H}-6 \alpha^{\prime}\right), 5.19(2 \mathrm{H}, d, J=3.9 \mathrm{~Hz}, \mathrm{H}-1$ and $\left.\mathrm{H}-1^{\prime}\right)$ and ${ }^{13} \mathrm{C}$ NMR, $\delta 93.36(\mathrm{C}-1, \mathrm{C}-$ $\left.1^{\prime}\right), 72.69$ (C-3, C-3'), 72.33 (C-5, C-5'), $71.22\left(\mathrm{C}-2, \mathrm{C}-2^{\prime}\right), 70.98\left(\mathrm{C}-4, \mathrm{C}-4^{\prime}\right)$ and $60.71\left(\mathrm{C}-6, \mathrm{C}-6^{\prime}\right)$.

\section{DISCUSSION}

Structure 1 was established based on ${ }^{1} \mathrm{H}$ and ${ }^{13} \mathrm{C}-\mathrm{NMR}$ data (Mekkawy et al. 1998), particularly $\mathrm{H} / \mathrm{H}$ (COSY) and H/C (HMQC and $\mathrm{HMBC}$ ) interactions and positive ion ESI-FT-ICR MS. The presence of the endoperoxide moiety was deduced from the low field position of the H-6 and H-7 resonances and appearance of ${ }^{13} \mathrm{C}$ NMR resonances at $\delta 82.12$ and 79.39 that were attributed to the oxygenated quaternary carbon atoms 5 and 8 , since all spectra indicated absence of acetylenic moieties that would have otherwise accounted for the latter signals. Many previous reports have suggested that peroxyergosterol may be an artifact rather than a true natural product (Nam et al. 2001). However, in these investigations the compound was detected even on TLC analysis of freshly obtained crude extracts, suggesting that the compound was indeed a true natural product. 5,8-Peroxyergosterol was previously reported as an antitumour compound (Kocor and Szalowska 1972, Brown and Jacobs 1975).

In previous studies, ergosterol derivatives exhibited antitumor, cytotoxic, rheumatoid arthritis and immune promoting properties (Brown and Jacobs 1975, Bok et al. 1999, Wasser and Weis 1999), the latter activity being a suitable attribute for food supplements. Therefore, due to the recently 
increasing demand for food supplements (functional foods), particularly for individuals with compromised immunity, the mushroom species Agaricus sp. aff. arvensis and L. edulis, and other Tanzanian wild mushroom species (Nyigo et al. 2005) that are rich in the above steroids, are interesting candidates for evaluation as potential functional food substrates.

Termitomyces letestui polar fractions yielded $\alpha, \alpha 1,1^{\prime}$-trehalose (2) whose structure was deduced from ${ }^{1} \mathrm{H}$ - and ${ }^{13} \mathrm{C}$-NMR spectral data (Breitmaeir and Voelter 1987, Duddeck et al. 1998), $[\alpha]_{\mathrm{D}}$ and m.p. values (Matsuura et al. 2002) and positive ion ESIFT-ICR MS that showed the molecular formula $\mathrm{C}_{12} \mathrm{H}_{22} \mathrm{O}_{11}$ for the disaccharide. The $\mathrm{H} / \mathrm{H}$ and $\mathrm{C} / \mathrm{H}$ interactions as observed in the COSY, HMQC and HMBC spectra revealed all the $\mathrm{CHO}$ connectivities and this unambiguously established the monosaccharide unit in structure 2 . The MS exhibited a weak fragment ion peak at $\mathrm{m} / \mathrm{z}$ 325 resulting from cleavage of a hydroxyl unit from the molecular ion, and another peak at $\mathrm{m} / \mathrm{z} 163$ due to a fragment ion for one of the two sugar residues. This and the fact that there was only one set of six signals in the ${ }^{13} \mathrm{C}$ NMR spectrum indicated that the isolated compound was a symmetrical disaccharide.

$\alpha, \alpha 1,1^{\prime}$-Trehalose which is hereby being reported for the first time in a Termitomyces species was previously shown to possess $\alpha$ glucosidase inhibition, exhibiting ability to suppress postprandial hyperglycemia caused by prolonged high blood glucose levels associated with diabetes (Moordian and Thurman 1999, Matsuura et al. 2002), and hence indicating the potential nutritional value of $T$. letestui for individuals susceptible to diabetes.

GC/MS analysis of the combined less polar fractions from $T$. letestui indicated the presence of the free fatty acids linoleic $\left(\mathrm{C}_{18: 2}\right)$, stearic $\left(\mathrm{C}_{18: 0}\right)$, oleic $\left(\mathrm{C}_{18: 1}\right)$, palmitic $\left(\mathrm{C}_{16: 0}\right)$, pentadecanoic $\left(\mathrm{C}_{15: 0}\right)$ and myristic
$\left(\mathrm{C}_{14: 0}\right)$ acid, as it was previously observed for other saprophytes, in comparison with symbiotrophs (Feofilova, 1998), thus further indicating that $T$. letestui possesses suitable attributes of a functional food substrate, since essential fatty acids are required for the promotion of a variety of body biochemical functions (Arasmus 1995).

It was surprising to note that the antimicrobial activity of the Agaricus sp. aff. arvensis EtOH extract was lost upon fractionation, indicating that either the activity was due to a combination of all the constituent compounds in the crude extract, or that the active compound(s) were labile, hence having been readily transformed into inactive products during fractionation.

\section{ACKNOWLEDGEMENTS}

Financial support through a Sida/SAREC grant to the Faculty of Science at the University of Dar es Salaam is gratefully acknowledged. LDB thanks the Germany Academic Exchange Services (DAAD) and NAPRECA for a Ph.D. fellowship under the DAAD-NAPRECA Fellowship Scheme. We thank Mr. Leonard B. Mwasumbi, a retired curator of the Herbarium of the Department of Botany at the University of Dar es Salaam for locating and identifying the investigated mushroom species. We wish to gratefully acknowledge the support of Professor Berhanu M. Abegaz from the University of Botswana for availing NMR analyses, and Ms E. Innocent from the Department of Chemistry at the University of Dar es Salaam for carrying out larvicidal assays.

\section{REFERENCES}

Arasmus U 1995 Fats that heal fats that kill, Alive Books, Burnaby, BC, Canada, pp. 1-465.

Bernardi MD, Vidari G, Finzi PV 1992 The chemistry of Lactarius fuliginosus and Lactarius pinicinus. Tetrahedron 48: 7331-7344. 
Breitmaier E, Voelter W 1987 Carbon-13 NMR spectroscopy high-resolution methods and applications in organic chemistry and biochemistry. $3^{\text {rd }}$ Edn. VCH Publishers Ltd., New York. pp. 379-399.

Bok JW, Lermer L, Chilton J, Klingeman HG, Towers GHN 1999 Antitumor sterols from the mycelia of Cordyceps sinensis. Phytochemistry 51: 891-898.

Brown LC, Jacobs JJ 1975 Isolation of ergosterol peroxide from Alternaria dianthicola. Aust. J. Chem. 28: 2317-2318.

Chobot V, Opletal L, Jahoda RL, Patel AV, Dackie GC, Blunder G 1997 Ergosta4,6,8,22-tetraen-3-one from edible fungus Pleurotus ostreatus (oyster fungus). Phytochemistry 45: 1669-1671.

Chulia AJ, Bernillon J, Favre-Bonvin J, Kaouadji M, Arpin N 1988 Isolation of $\beta-N$ - $(\gamma$-glutamyl)-4formylphenylhydrazine (agaritanal) from Agaricus campestris. Phytochemistry 27: 929-930.

Duddeck H, Dietrich W, Tóth G 1998 Structure elucidation by modern NMR. A workbook, $3^{\text {rd }}$ Edn., Steinkopff Springer, New York, pp. 192-193.

Feofilova EP 1998 Current trends in studies of biologically active substances of basidial fungi. Appl. Biochem. Microbiol. 34: 541-550.

Harkonen M, Niemela T, Mwasumbi L 2003 Tanzanian mushrooms. Edible, harmful and other fungi. Norrlinia 10: 41-42.

Joseph CC, Ndoile MM, Malima RC, Nkunya MHH 2004 Larvicidal and mosquitocidal extracts, a coumarin, isoflavonoids and pterocarpans from Neurautanenia mitis. Trans. Royal Soc. Trop. Med. Hyg. 98: 451-455.

Karhula P, Harkonen M, Saarimaki T, Verbeken A, Mwasumbi LB 1998 Tanzanian mushrooms and their uses: Lactarius. Kerstenia 38: 49-68.

Kawakishi H, Katsumi R, Sazawa T, Mizuno T, Hagiwara T, Nakamura T 1998 Cytotoxic steroids from the mushroom Agaricus blazei. Phytochemistry 27: 2777-2779.

Kobayashi M, Tsuru R, Todo K, Mitsuhashi H 1973 Marine sterols - II. Asterosterol, a new $\mathrm{C}_{26}$ sterol from Asterias amurensis Lütken. Tetrahedron 29: 1193-1196.

Kocor M, Szalowska S 1972 Constituents of higher fungi. The sterols from Cantharellus cibarius Bull. Acad. Polynaise Sci. 20: 515-519.

Kulkarni RK 1990 Mannitol metabolism in Lentinus edodes, the Shiitake mushroom. Appl. Environ. Microbiol. 56: 250-253.

Matsuura H, Asakwa C, Kurimoto M, Mizutani J $2002 \alpha-$-Glucosidase inhibitor from the seeds of balsam pear (Momordica charantia) and the fruit bodies of Grifola frondosa. Biosci. Biotechnol. Biochem. 66: 1576-1578.

Mdachi SJM, Nkunya MHH, Nyigo VA, Urasa IT 2004 Amino acid composition of some Tanzanian wild mushrooms. Food Chem. 86: 179-182.

Mekkawy SE, Meselhy RM, Nakamura N, Tezuka Y, Hattori M, Kakiuchi N, Shimotohno K, Kawahata T, Otake T 1998 Anti-HIV-1 and anti-HIV-1protease substances from Ganoderma lucidum. Phytochemistry 49: 1651-1657.

Meyer BN, Ferrigni NR, Putnam JE, Jacobsen LB, Nichols DE, McLaughlin JL 1982 Brine shrimp: A convenient general bioassay for active plant constituents. Planta Med. 45: 31-34.

Moordian AD, Thurman JE 1999 Drugs therapy of postprandial hyperglycemia. Drugs 57: 19-29.

Moshi MJ, Joseph CC, Innocent E, Nkunya MHH (2004): In-vitro antibacterial and antifungal activity of extracts and compounds from Uvaria scheffleri. Pharm. Biol. 42: 269-273.

Nam KS, Jo YS, Kim YH, Hyun JW, Kim HW 2001 Cytotoxic activities of acetoxyscirpenediol and ergosterol peroxide from Paecilomyces tenuipes. Life Sci. 69: 229-237. 
Nyigo VA, Baraza LD, Nkunya MHH, Mdachi SJM, Joseph CC, Waziri A 2005 Chemical constituents and cytotoxicity of some Tanzanian wild mushrooms, Tanz. J. Sci. 31: 1-3.

Ohsawa T, Yukwaw M, Takao C, Murayama M, Bando H 1992 Studies on constituents of fruit body of Polyporus umbellatus and their cytotoxic activity. Chem. Pharm. Bull. 40: 143-147.

Pegler DN 1977 A preliminary Agaric flora of East Africa. Kew Bull. 35: 475-491.

Pouchert CJ 1983 The Aldrich library of NMR spectra. Aldrich Chemical Company, Inc., USA. $2^{\text {nd }}$ Edn., pp. 901-916.

Qi J, Ojika M, Sakagami Y, Chikusa K 2000 Termitomycesphins A-D, Novel neuritogenic cerebrosides from the edible
Chinese mushroom Termitomyces albuminosus. Tetrahedron 56: 5835-5841

Stadler M, Sterner O 1998 Production of bioactive secondary metabolites in the fruit bodies of macrofungi as a response to injury. Phytochemistry 49 : 1013-1019.

Stahl E 1969 Thin-layer chromatography, a laboratory handbook. Springer-Verlag, New York, p. 857.

Sterner O, Anke H 1995 Toxic terpenoids isolated from higher fungi. Czech Mycol. 48: 39-52.

Wasser SP, Weis AL 1999 Medicinal properties of substances occurring in higher Basidiomycetes mushrooms: Current perspectives (review). Int. J. Med. Mushr. 1, 31-62. 